\title{
Chemical characterization of the pulp, peel and seeds of cocona (Solanum sessiliflorum Dunal)
}

\author{
Caracterização química da polpa, casca e sementes de cocona \\ (Solanum sessiliflorum Dunal)
}

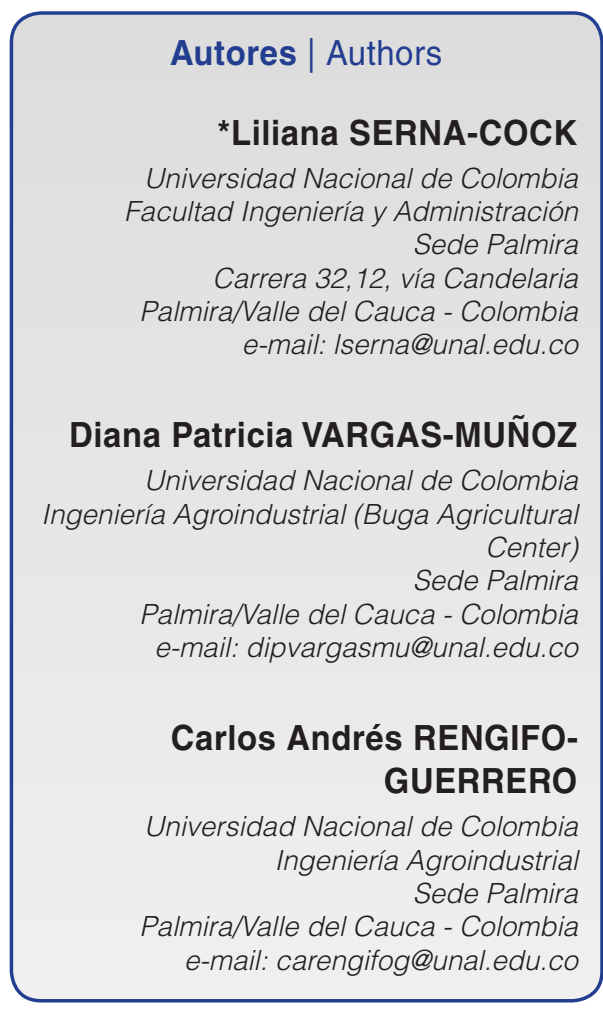

*Autor Correspondente / Corresponding Author

Received: Aug. 05, 2014

Approved: Nov. 04, 2015

\section{Summary}

The chemical characterization of the pulp, peel and seeds of cocona (Solanum sessiliflorum Dunal) was determined. In artisanal fruit processing, 26.3\% of peel and $9.7 \%$ of seeds were obtained. The seeds showed a high potential for the development of value-added products because of their dry matter contents (23.46\%) as follows: carbohydrate (69.37\% dry basis (d.b.)), nitrogen $(3.18 \mathrm{~g} / 100 \mathrm{~g}$ of seed d.b.), K (0.023 g/100 g of seed d.b.), Fe (0.0185 g/100 g of seed d.b.) and dietary fiber ( $21.27 \mathrm{~g} / 100 \mathrm{~g}$ of seed d.b.). The carbohydrate, dietary fibre and mineral contents of the pulp, peel and seeds also highlighted the agroindustrial potential of the fruit in that these constituents could be used to develop functional foods, food additives, preparations for functional diets and dietary supplements.

Key words: Cocona; Amazonian fruits; Chemical composition; By-products.

\section{Resumo}

A caracterização química da polpa, casca e sementes de cocona (Solanum sessiliflorum Dunal) foi determinada. No processamento artesanal da fruta foram obtidos $26.3 \%$ de casca e $9.7 \%$ de sementes. As sementes apresentaram um alto potencial para o desenvolvimento de produtos com valor agregado devido ao seu conteúdo de matéria seca (23,46\%), como seque: carboidrato ( $69,37 \%$ base seca (b.s.)), nitrogênio (3,18 g/100 g de sementes, b.s.), K (0,023 g/100 g de sementes, b.s.), Fe $(0,0185 \mathrm{~g} / 100 \mathrm{~g}$ de sementes, b.s.) e fibra dietética $(21,27 \mathrm{~g} / 100 \mathrm{~g}$ de sementes, b.s.). O teor de carboidrato, fibra dietética e conteúdos minerais da polpa, casca e sementes também evidenciaram o potencial agroindustrial da fruta, visto que estes constituintes podem ser usados para desenvolver alimentos funcionais, aditivos para alimentos, preparações para dietas funcionais e suplementos dietéticos.

Palavras-chave: Cocona; Frutas da Amazonia; Composição química; Sub-produtos. 


\section{Introduction}

The agroindustrialisation of fruits generates many residues, represented in most cases by the peel and seeds, which, when discarded into the environment, cause problems that may include putrefaction, unpleasant odours, landscape deterioration, the contamination of soil and water bodies and the spread of pests. To mitigate these problems, some researchers have used agroindustrial fruit residues to generate value-added products, such as residues from lemon (JANATI et al., 2012), orange (LLANOS et al., 2008), mango (GUZMÁN et al., 2010) and banana (DORMOND et al., 2011), amongst others, have been used in animal feeds. Pineapple residues have been used to produce xylose (RAMÍREZ et al., 2012) and synthesize lactic acid (ARAYA-CLOUTIER et al., 2010) and fruit seeds, such as those from passion fruit, blackberry and lulo, have been used for the extraction of fatty acids (CERÓN et al., 2012). Residues from the agroindustrialization of tangerines are suitable for the extraction of essential oils (NAVARRETE et al., 2010), and guava seeds have been used to produce ethanol and lactic acid (SERNA et al., 2013a, b).

Other research has attempted to identify means to increase the value of residues generated during the processing of fruit, by transforming seeds and peels into nutraceutical products or natural preservatives (ALZATE et al., 2011), which are used in food products and are beneficial to consumer health.

Some agroindustrial residues have been used to generate other types of value-added products, such as, for example, cellulose nanofibers, obtained from sugar cane bagasse and used to reinforce the polymer matrices of high-density polyethylene and polypropylene (ESPITIA, 2010). Ethanol has been obtained from sugar cane and corn residues (CARDONA et al., 2005), vegetable residues (FONSECA; MATURANA, 2010), coffee mucilage (RUIZ; ARIAS, 2001) and chicken feathers (SERNA et al., 2013c), amongst other sources.

The physical and chemical characterization of both the whole fruits and the fruit residues generated during their agroindustrialization is crucial to finding innovative value-added uses for these residues.

Cocona (Solanum sessiliflorum Dunal) is a fruit with an exotic flavour which is indigenous to the Amazon region and used by the natives and inhabitants of this region for food, medicine and cosmetics (QUIJANO; PINO, 2006). Furthermore, this fruit is highly regarded for the preparation of jellies, jams, pasta, pickles and sweets (ARGOTE at al., 2013). Cocona seed and peel residues with agroindustrial potential are generated during the artisanal processing. Therefore, the aim of the present study was to determine the agroindustrial potential of cocona pulp, peel and seeds by characterizing the physicochemical properties of these three fruit components. This potential was determined from the yields of the following components; minerals, sugars, protein, fat, soluble and insoluble dietary fibre, ascorbic acid and soluble solids; and their digestibility, acidity and $\mathrm{pH}$.

\section{Material and methods}

\subsection{Obtaining the fruits}

Ecotype II cocona fruits, reddish brown in colour, with a ripeness degree of 5 were used (AGRONET, 2006). The cocona fruits originated from non-technified cultivars in Puerto Caicedo, Putumayo Department, Colombia. The fruits were washed with 200 ppm sodium hypochlorite and dried with absorbent paper.

\subsection{Characterization of the pulp, peel and seeds}

Forty fruits were used for the characterization. Their peels were removed with a conventional kitchen peeler, and the samples of pulp and seeds obtained using a pulper (Philips model HR1764, Brazil). Each of the three fruit samples (pulp, peel and seeds) was weighed on a precision balance (Denver APX-323, Fisher Scientific, Pittsburgh, PA, USA) and the percent yield of pulp, peel and seed calculated using Equation 1.

$$
\text { Yield }=\frac{W_{1}}{W_{0}} \times 100
$$

where $W_{0}$ is the average weight of 40 cocona fruits and $W_{1}$ is the average weight of the pulp, peel or seeds obtained from these fruits.

In addition, the concentration of each component with respect to the whole fruit was calculated using Equation 2.

$$
\text { Concentration }=\frac{\% \text { d.b. } \times(\text { D.M. })}{100} \times \frac{\text { Yield }}{100}
$$

where $\%$ d. b. is the dry basis percentage of a component, $\%$ D.M is the dry matter of each component and Yield is the pulp, peel or seed yield.

The pulp, peel and seed samples obtained from the 40 fruits were divided into two batches, each of which was weighed on the Denver APX-323 precision scale. One batch was maintained in the fresh state and the other dried at $65^{\circ} \mathrm{C}$ in a convection oven (model Ed $115 \mathrm{UL}$, Binder Labortechnik, Tuttlingen, Germany). The dried samples were ground in a mill (Fritsch, Idar-Oberstein, Germany) at 8000 rpm using a 1-mm sieve and stored in plastic bags at $25^{\circ} \mathrm{C}$ until further use.

The Wendee analysis was carried out on each type of fruit sample, determining the following parameters: the percentage of dry matter (HELRICH, 1990a, b) method 934.06; ash content, method 942.05 using a muffle furnace 
(model 550-58, Fisher Scientific, USA); protein content (Kjeldahl method, Helrich (1990c, d), method 32.1.22; ether-extractable content, method 920.39; cellulose, hemicellulose and lignin contents (Van Soest Analysis) Cunniff (1997), method 973.18; dietary fibre (HORWITZ, 2000b), method 978.10 - enzymatic technique); and in vitro digestibility (HORWITZ, 2000b), method 971.09 enzymatic and gravimetric technique).

The fresh samples were used to determine other physicochemical properties, including total soluble solids (TSS) (HELRICH, 1990e), method 932.12 using a digital refractometer (model AR200, Reichert Technologies, Depew, NY, USA), pH by a potentiometric method (SevenEasy S30 conductivity meter, Mettler-Toledo, Schwerzenbach, Switzerland), total titratable acidity (TTA) (HORWITZ, 2000a), method 942.15A, expressed as percentage of citric acid. In addition, the ascorbic acid content was determined using an assay kit (Reflectoquant RQflex 10, Merck, Darmstadt, Germany).

Regarding the mineral content, phosphorus and boron were determined by ultraviolet-visible spectroscopy (UV-Vis) (DAWSON, 1986); and potassium, calcium, magnesium, sodium and trace elements, such as copper, iron, zinc and magnesium, were determined by atomic absorption spectroscopy (VARGA; KOLODZIEJ, 1974).

The analyses were carried out with 2 replicates and expressed as the percentage (\% d.b.) and g/100 g of the whole fruit, considering the performance of each component in the fruit.

\section{Results and discussion}

The yields of pulp, peel and seeds were 64\%, $26.3 \%$ and $9.7 \%$, respectively. These results for yield indicated that in the agroindustrialisation of cocona fruit, each ton of fresh fruit processed in an artisan way yields 0.64 tons of pulp and 0.36 tons of residues, represented by peel and seed. These yields are consistent with those of Barbosa-Pires et al. (2006), who indicated that this fruit generated approximately $30 \%$ residues.
The whole fruit contained $10.94 \%$ dry matter and carbohydrates were the primary component of the pulp, peel and seeds (Table 1). Considering the yield of each component of the fresh fruit (Table 1), the pulp and peel were observed to contribute similar amounts of carbohydrate and the peel and seeds contributed similar amounts of protein.

Of the fruit fractions, the pulp contributed the greatest amount of dry matter, ash, protein and carbohydrates.

One hundred grams of the seeds were found to contain more dry matter, protein and ether-extractable contents than were found in $100 \mathrm{~g}$ of either the pulp or peel. The protein content of the peel was quite similar to that of the pulp.

Yuyama et al. (2007) determined the chemical composition (d.b.) of the pulp in eight varieties of cocona from the Manaus region (Brazil) and found levels of protein between $4.8 \%$ and $7 \%$, carbohydrates between $51 \%$ and $81 \%$ and ether-extractable contents between $3.4 \%$ and $20 \%$. The results of the present study, corresponding to cocona crops from the Colombian Amazon region, are in the same ranges as described by YUYAMA et al. However, the studies on cocona pulp by Barbosa-Pires et al. (2006) reported higher values for protein, ether-extractable content, ash and carbohydrates than those obtained in the present study. Similarly, Marx et al. (1998) reported a higher dry matter content in cocona pulp than that obtained in the present study (9.5\%).

A comparison of the dry matter and protein contents of cocona pulp with those of the pulps of other Amazonian fruits, showed that cocona had $80 \%$ more dry matter than arazá and the same amount of protein as cupuaçu (ROGEZ et al., 2004). However acai (Euterpe oleraceae Mart.), had higher protein and ether-extractable contents than cocona (GORDON et al., 2012).

Reports on the chemical composition of cocona peel and seeds were not found in the scientific literature.

Table 1. Proximate and Van Soest analysis of Cocona fruit (Solanum sessiliflorum Dunal).

\begin{tabular}{|c|c|c|c|c|c|c|c|}
\hline & \multirow[b]{2}{*}{ Component } & \multicolumn{2}{|c|}{ Pulp } & \multicolumn{2}{|c|}{ Peel } & \multicolumn{2}{|c|}{ Seed } \\
\hline & & $\begin{array}{c}\% \\
\text { (d.b.) }\end{array}$ & $\begin{array}{l}\mathrm{g} / 100 \mathrm{~g} \text { of } \\
\text { whole fruit }\end{array}$ & $\begin{array}{c}\% \\
\text { (d.b.) }\end{array}$ & $\begin{array}{l}\mathrm{g} / 100 \mathrm{~g} \text { of } \\
\text { whole fruit }\end{array}$ & $\begin{array}{c}\% \\
\text { (d.b.) }\end{array}$ & $\begin{array}{l}\mathrm{g} / 100 \mathrm{~g} \text { of } \\
\text { whole fruit }\end{array}$ \\
\hline \multirow{5}{*}{$\begin{array}{c}\text { Proximate } \\
\text { Analysis }\end{array}$} & Dry matter & 7.27 & 4.65 & 13.41 & 3.53 & 23.46 & 2.28 \\
\hline & Ash & 10.14 & 0.47 & 4.80 & 0.17 & 3.62 & 0.08 \\
\hline & Protein ${ }^{\star}$ & 8.74 & 0.41 & 8.38 & 0.30 & 15.08 & 0.34 \\
\hline & Ether extractable content & 6.37 & 0.30 & 0.97 & 0.03 & 11.93 & 0.27 \\
\hline & Carbohydrates & 74.75 & 3.48 & 85.85 & 3.03 & 69.37 & 1.58 \\
\hline \multirow{3}{*}{ Van Soest } & Cellulose & 8.27 & 0.38 & 12.58 & 0.44 & 30.81 & 0.70 \\
\hline & Hemicellulose & 5.26 & 0.24 & 4.04 & 0.14 & 21.90 & 0.50 \\
\hline & Lignin & 2.41 & 0.11 & 16.36 & 0.58 & 14.40 & 0.33 \\
\hline
\end{tabular}

${ }^{*}$ Conversion factor 6.25 . 
The carbohydrate and protein contents of cocona peel and seeds indicate that these residues from the artisanal agroindustry are usable sources of carbon and nitrogen as substrates for organic fermentation. It is well known that the fermentation industry uses inorganic sources of nitrogen in industrial-scale fermentations (RODRÍGUEZ; PIÑEROS, 2009), and this resource has become a limiting factor for the production of organic products obtained by fermentation.

Barbosa-Pires et al. (2006) proposed using the by-products of pulped cocona in the preparation of candy, which is commercialized in some areas of Brazil.

The agroindustrial potential and economic viability of a fruit depend, in part, on its moisture content, with the most promising materials showing higher dry matter contents (YUYAMA et al., 2007). Thus the dry matter, protein and carbohydrate contents of cocona seeds make this residue ideal for developing value-added products. Conversely, the high moisture content of the peel $(86.59 \%)$ and pulp (92.73\%) make these products susceptible to enzymatic and microbiological changes (BARRETO et al., 2009). Therefore, an alternative for cocona pulp and peel would be dehydration by freeze drying or some other drying method. Authors such as Silva et al. (2010) suggest that the best alternative for the agroindustrialisation of products with high moisture contents is dehydration, because drying increases the shelf life and reduces packaging and transportation costs due to the reduced weight.

Nutritionally, the major component in cocona is carbohydrate, which is primarily found in the pulp and peel of the fruit. According to Yuyama et al. (2007) and Silva et al. (2010), the carbohydrate concentration is directly linked to the energy value of the fruit, indicating that cocona and its by-products could be used in diets for overweight or obese people or those with certain energy restrictions. The significance of fruit carbohydrates arises from their relatively high proportion of dietary fibre and cell wall fibre, which decrease the absorption rate of fruit sugars, resulting in a lower glycaemic response. It is thus recommended that fruit consumption be increased to maintain health and protect against certain diseases, including diabetes, cancer and cardiovascular disease (DURÁN et al., 2012).

Table 1 shows the results for the Van Soest analysis (hemicellulose, cellulose and lignin). The peels contained the highest lignin content $(16.36 \mathrm{~g} / 100 \mathrm{~g})$, and the seeds the highest cellulose content $(30.81 \mathrm{~g} / 100 \mathrm{~g})$. The seeds and pulp contributed the most dietary fibre, in similar amounts (13.61 and $13.18 \mathrm{~g} / 100 \mathrm{~g}$ of whole fruit). Yuyama et al. (2012) found lower values for total dietary fibre in cocona pulp and peel, at $1.68 \mathrm{~g} / 100 \mathrm{~g}$, and $4.38 \mathrm{~g} / 100 \mathrm{~g}$, respectively. The dietary fibre content of cocona pulp was higher than that reported for other
Amazonian fruits, such as acai $(5.92 \mathrm{~g} / 100 \mathrm{~g})$ and camu-camu $(0.57 \mathrm{~g} / 100 \mathrm{~g})$.

Similarly, cocona peel and seeds ( 50.15 and $68.12 \%$, respectively) have significant dietary fibre when compared with passion fruit seeds (64.8\%) (CHAU; HUANG, 2004), mango pulp (44.7\%) (AJILA et al., 2007) and Persian lime peel (66.7\%) (UBANDO-RIVERA et al., 2005). This similarity shows that cocona fruit, including its agroindustrialization residues, can be an important supplement to the human diet, providing significant amounts of dietary fibre, which is of great interest from a nutritional standpoint. Moreover, because of their soluble and insoluble dietary fibre contents, each of the components can be used to formulate prebiotic tablets that are beneficial in preventing colon cancer. The components can also be used in slimming formulations because the water-retaining capacity of dietary fibre (especially soluble fibre) is well known for increasing satiety and decreasing nutrient absorption time (GRIGELMO-MIGUEL; MARTIN-BELLOSO, 1999; YUYAMA et al., 2012). In addition, the components can be included in natural formulations to prevent increases in blood cholesterol, because a relationship has been proven between the consumption of dietary fibre and decreases in the intestinal absorption of cholesterol (AJILA et al., 2007).

Table 2 shows the mineral contents of the cocona pulp, peel and seeds. The analysis of the mineral composition of the cocona fruit indicated that the element potassium was found in relatively high proportions in the three fruit components.

The potassium content of cocona is due to fertilization and the Amazon soil type (SILVA-FILHO et al., 2005) and that reported in the present study is consistent with that reported by Barbosa-Pires et al. (2006) and Silva-Filho et al. (2005), who found that the potassium content of cocona fruits was high when compared with the iron, calcium, phosphorus, magnesium and zinc contents. The ingestion of large amounts of potassium protects against hypertension; the recommended minimum potassium intake per person per day being $2 \mathrm{~g}$ (MIGUEL; SARMIENTO, 2009), which can be found in citrus fruits, tomatoes, cabbage and cocona.

Of the microelements, iron was the mineral found in the greatest proportion in the three cocona components, although the seeds provided more than the pulp or peel. Similarly, the seeds contained more of other minerals, such as $\mathrm{Ca}, \mathrm{Zn}, \mathrm{Mn}$ and P. In general, of the whole fruit, the pulp provided the highest mineral content.

The mineral concentrations found in the three fruit components suggest that cocona could be used to formulate dietary supplements for consumption by people requiring a Na-restricted diet.

Barbosa-Pires et al. (2006) found higher $\mathrm{Ca}$ (13.68 mg/100 g), Mg (17.49 mg/100 g), K (35.79 mg/100 g) 
Table 2. Mineral content of cocona (Solanum sessiliflorum Dunal).

\begin{tabular}{|c|c|c|c|c|c|c|}
\hline \multirow[b]{2}{*}{ Component } & \multicolumn{2}{|c|}{ Pulp } & \multicolumn{2}{|c|}{ Peel } & \multicolumn{2}{|c|}{ Seed } \\
\hline & $\begin{array}{c}\% \\
\text { (d.b.) }\end{array}$ & $\begin{array}{l}\mathrm{mg} / 100 \mathrm{~g} \text { of } \\
\text { whole fruit }\end{array}$ & $\begin{array}{c}\% \\
\text { (d.b.) }\end{array}$ & $\begin{array}{l}\mathrm{mg} / 100 \mathrm{~g} \text { of } \\
\text { whole fruit }\end{array}$ & $\begin{array}{c}\% \\
\text { (d.b.) }\end{array}$ & $\begin{array}{l}\mathrm{mg} / 100 \mathrm{~g} \text { of } \\
\text { whole fruit }\end{array}$ \\
\hline $\mathrm{Ca}$ & 0.0070 & 0.3257 & 0.0060 & 0.2116 & 0.0080 & 0.1820 \\
\hline Mg & 0.0040 & 0.1861 & 0.0040 & 0.1411 & 0.0100 & 0.2276 \\
\hline$K$ & 0.1150 & 5.3507 & 0.0400 & 1.4107 & 0.0230 & 0.5234 \\
\hline $\mathbf{P}$ & 0.0030 & 0.1396 & 0.0010 & 0.0353 & 0.0020 & 0.0455 \\
\hline $\mathrm{Na}$ & N.D. & N.D. & N.D. & N.D. & N.D. & N.D. \\
\hline $\mathrm{Cu}$ & 0.0003 & 0.0140 & 0.0003 & 0.0110 & 0.0003 & 0.0062 \\
\hline $\mathrm{Zn}$ & 0.0000 & 0.0001 & N.D. & N.D. & 0.0008 & 0.0192 \\
\hline Mn & 0.0004 & 0.0189 & 0.0004 & 0.0135 & 0.0012 & 0.0275 \\
\hline $\mathrm{Fe}$ & 0.0064 & 0.2982 & 0.0022 & 0.0769 & 0.0185 & 0.4212 \\
\hline B & 0.0017 & 0.0786 & 0.0014 & 0.0497 & 0.0019 & 0.0435 \\
\hline
\end{tabular}

$\mathrm{ND}=$ not detectable

Table 3. Chemical properties of cocona components (Solanum sessiliflorum Dunal).

\begin{tabular}{lccc}
\multicolumn{1}{c}{ Parameter } & Pulp & Peel & Seeds \\
Ascorbic acid (\%) & $3.51 \pm 0.33$ & $<1.5 \%$ & $<1.5 \%$ \\
pH & $3.31 \pm 0.01$ & $4.09 \pm 0.015$ & $5.69 \pm 0.14$ \\
Total soluble solids (\%) & $6.30 \pm 0.3$ & $<0.5 \%$ & $1.3 \pm 0.2$ \\
Citric acid (\%) & $1.91 \pm 0.01$ & $<0.1 \%$ & $0.04 \pm 0.003$ \\
\hline
\end{tabular}

and $P(21.27 \mathrm{mg} / 100 \mathrm{~g})$ contents in cocona pulp than those reported in the present study. The differences in trace elements found between the present study and that of Barbosa-Pires et al. (2006) are due to variability in soil and climatic conditions (crop location, solar cycle and climate) (BARRETO et al., 2009).

Cocona pulp has more $\mathrm{K}$ and $\mathrm{P}$ than that of cupuaçu (Theobroma grandiflorum) (1.37 and $0.06 \mathrm{mg} / 100 \mathrm{~g}$ of pulp respectively (ROGEZ et al., 2004).

Table 3 shows the results for ascorbic acid, $\mathrm{pH}$, total solids and titratable acidity (citric acid). The ascorbic acid content was higher than that reported by Barreto et al. (2009), who found values of $3 \%$ for cocona pulp. The ascorbic acid content of cocona pulp makes the fruit a good source of antioxidants, which can prevent the cell damage caused by oxidation and hence the pulp could be used in the formulation of antioxidant complexes. Barbosa-Pires et al. (2006) reported a pH of 4.12, total solids of $6.12 \%$ and an ascorbic acid concentration of $1.92 \mathrm{mg} / 100 \mathrm{~g}$ for cocona pulp.

The in vitro digestibility of the cocona peel and pulp was $55.38 \%$ and $81.33 \%$, respectively, showing that these products could be easily digested. The digestibility of the seeds was much lower (27.99\%). These results indicated that both the pulp and the peel of cocona could be used as food for humans, and one option for their easy consumption could be the incorporation of these two components in the freeze-dried form, as crispy additives to breakfast cereals. These additives would improve the prebiotic features of breakfast cereals, which are considered to have massive consumption worldwide.

Cocona seeds transformed into cocona flour by drying and grinding could be marketed as a prebiotic product. Such a flour would be a healthy choice in formulations for human consumption, because the unabsorbed fraction would increase faecal matter, with the consequent trapping of toxins (YUYAMA et al., 2012).

The microbial modification of the lignocellulosic residues of cocona peels and seeds is another promising alternative for the production of more digestible foods for human or animal consumption. These materials could be used as a source of carbon and nitrogen in fermentation substrates, considering that the fermentation industry uses inorganic sources of nitrogen for fermentation, a use that constitutes a well-known limiting factor for the production of organic products obtained by fermentation.

\section{Conclusions}

Cocona seed is ideal for developing value-added products because of its high contents of dry matter, carbohydrate, fat, protein, Fe, Ca, Zn, Mn, P and dietary fibre. Cocona peel and pulp provide similar amounts of carbohydrates and proteins. The pulp and seed provide similar amounts of dietary fibre. Therefore, both cocona pulp and the residues generated in the artisanal cocona agroindustry have a variety of potential uses. The mineral concentrations found in the three cocona components make them suitable for use in dietary supplements. 
The ascorbic acid content of the cocona pulp makes the fruit a good source of antioxidants useful for preventing the cell damage caused by oxidation.

\section{References}

AGRONET. Share business. 2006. Available from: <wwW. agronet.com>. Access in: 18 oct. 2012.

AJILA, C. M.; BHAT, S. G.; PRASADA RAO, U. J. Valuable components of raw and ripe peels from two Indian mango varieties. Food Chemistry, London, v. 102, n. 4, p. 1006-1011, 2007. http://dx.doi.org/10.1016/j.foodchem.2006.06.036.

ALZATE, L.; ARTEAGA, D.; JARAMILLO, Y. Evaluation to potential uses of the carob tree's fruit (Hymenaea Courbaryl L.) -shel and seeds- as a natural preserver for food. Revista Lasallista de Investigación, Caldas, v. 8, n. 1, p. 90-95, 2011.

ARAYA-CLOUTIER, C.; ROJAS-GARBANZO, C.; VELÁZQUEZCARILLO, C. Síntesis de ácido láctico, a través de la hidrólisis enzimática simultanea a la fermentación de un medio a base de un desecho de piña (Ananas comosus), para su uso como materia prima en la elaboración de ácido poliláctico. Revista Iberoamericana de Polímeros, Bilbao, v. 11, n. 7, p. 407-416, 2010.

ARGOTE F. E., VARGAS D. P., VILLADA H. S. Investigación de mercado sobre el grado de aceptación de mermelada de cocona en Sibundoy, Putumayo. Revista Científica Guillermo de Ockham, Colombia, v. 11, n. 2, p. 197-206, 2013.

BARBOSA-PIRES, A. M.; SANTIAGO, P.; MOREIRA, P.; GOMES, J. C.; MOTA, A. Caracterização e processamento de cubiu (Solanum sessiliflorum). Ceres, Viçosa, v. 53, n. 307, p. 309-316, 2006.

BARRETO, G.; BENASSI, M.; MERCADANTE, A. Bioactive compounds from several tropical fruits and correlation by multivariate analysis to free radical scavenger activity. Journal of the Brazilian Chemical Society, Campinas, v. 20, n. 10, p. 1856-1861, 2009. http://dx.doi.org/10.1590/S010350532009001000013

CARDONA, C.; SÁNCHEZ, O.; MONTOYA, M.; QUINTERO, J. Producción de atenol carburante: material lignocelulósico una nueva alternativa. Ingeniería de recursos naturales y del ambiente, Cali, v. 2, n. 1, p. 47-55, 2005.

CERÓN, A.; OSORIO, O.; HURTADO, A. Identificación de ácidos grasos contenidos en los aceites extraídos a partir de semillas de tres diferentes especies de frutas. Acta Agronomica, Bogotá, v. 61, n. 2, p. 126-132, 2012.

CHAU, C. F.; HUANG, Y. L. Characterization of passion fruit seed fibres: a potential fibre source. Food Chemistry, London, v. 85 , n. 2, p. 189-194, 2004. http://dx.doi.org/10.1016/j. foodchem.2003.05.009.

CUNNIFF, P. (Ed.). Fiber (acid detergent) and lignin in animal feed (Method 973.18). In: CUNNIFF, P. (Ed.). Official methods of analysis of the Association Of Official Analytical Chemists 16th ed. Gaithersburg: AOAC, 1997

DAWSON, J. B. Analytical atomic spectroscopy in biology and medicine. Fresenius Journal of Analytical Chemistry, Berlin, v. 324, n. 5, p. 463-471, 1986.

DORMOND, H.; ROJAS, A.; BOSCHINI, C.; MORA, G.; SIBAJA, G. Evaluación preliminar de la cáscara de banano maduro como material de ensilaje, en combinación con pasto King Grass (Pennisetum purpureum). Revista electrónica de las sedes regionales de la Universidad de Costa Rica, Costa Rica, v. 12, n. 23, p. 17-31, 2011.

DURÁN, S.; CARRASCO, E.; ARAYA, M. Food and diabetes. Nutrición Hospitalaria, España, v. 27, n. 4, p. 1031-1036, 2012.

ESPITIA, H. Aislamiento de nanofibras de ceulosa a partir de residuos agroindustriales de fique y caña de azúcar, con potencial aplicación en reforzamiento de polímeros termoplásticos. 2010. 58 f. Disertación (Maestría en Ciencias - Química)-Facultad de Ciencias, Universidad Nacional de Colombia, Medellin, 2010

FONSECA, E.; MATURANA, G. Aprovechamiento de los residuos vegetales de una central de abastos para la obtención de etanol. Revista Épsilon, Bogotá, n. 14, p. 21-31, 2010.

GORDON, A.; GIL, A. P.; CORREA, L. M.; CORDEIRO, S.; ARAUJO, C. M.; MARINO, C.; ANDRADE, R.; FRIEDRICH, F.; MARTINS, V.; MARX, F. Chemical characterization and evaluation of antioxidant properties of Açaí fruits (Euterpe oleraceae Mart.) during ripening. Food Chemistry, London, v. 133, p. 256-263, 2012.

GRIGELMO-MIGUEL, N.; MARTIN-BELLOSO, O. Comparison of dietary fiber from by-products of processing fruits and greens and from cereals. Food Science and Technology, London, v. 32, n. 8, p. 503-508, 1999. http://dx.doi.org/10.1006/fstl.1999.0587.

GUZMÁN, O.; LEMUS, C.; BUGARIN, J.; BONILLA, J.; LY, J. Ensilado de residuos de mango (mangifera indica L.) para la alimentación animal: características fermentativas. Revista computadorizada de producción porcina, La Habana, v. 17, n. 3, p. 218-24, 2010.

HELRICH, K. (Ed.). Moisture in dried fruits (Method 934.06). In: HELRICH, K. (Ed.). Official methods of analysis of the Association of Official Analytical Chemists. 15th ed. Arlington: AOAC, 1990a. p. 911-12.

HELRICH, K. (Ed.). Cenizas (Method 942.05). In: HELRICH, K. (Ed.). Official methods of analysis of the Association of Official Analytical Chemists. 15th ed. Arlington: AOAC, $1990 \mathrm{~b}$.

HELRICH, K. (Ed.). Método Kjeldhal (Method 32.1.22). In: $\mathrm{HELRICH}$, K. (Ed.). Official methods of analysis of the Association of Official Analytical Chemists. 15th ed. Arlington: AOAC, 1990c. 
HELRICH, K. (Ed.). Ethereal extract (Method 920.39). In: HELRICH, K. (Ed.). Official methods of analysis of the Association of Official Analytical Chemists. 15th ed. Arlington: AOAC, 1990d.

HELRICH, K. (Ed.). Total soluble solids (Method 932.12). In: HELRICH, K. (Ed.). Official methods of analysis of the Association of Official Analytical Chemists. 15th ed. Arlington: AOAC, 1990e.

HORWITZ, W. (Ed.). Fruits and fruit products: acidity (titratable) of fruit products. (Method 942.15A). In: HORWITZ, W. (Ed.). Official methods of analysis of the Association of Official Analytical Chemists. 17th ed. Gaithersburg: AOAC, 2000a.

HORWITZ, W. (Ed.). Official methods of analysis of Association of Official Analytical Chemists. 17th ed. Gaithersburg: AOAC, 2000b.

JANATI, S.; BEHESHTI, H.; FEIZY, J.; FAHIM, N. Chemical composition of lemon (Citrus limon) and peels: its considerations as animal food. GIDA, Mashhad, v. 37, n. 5, p. 267-71, 2012.

LLANOS, D.; MOSQUERA, D.; CUBA, F. Ensiling potential of orange fruit wastes (Citrus sinensis). Revista Ciencias técnicas agropecuarias, La Habana, v. 17, n.2, p. 41-44, 2008.

MARX, F.; ANDRADE, E. H. A.; MAIA, J. G. Chemical composition of the fruit of Solanum sessiliflorum. Zeitschrift fur Lebensmitteluntersuchung und Forschung A, Berlin, v. 206, n. 5, p. 364-366, 1998. http://dx.doi.org/10.1007/s002170050274.

MIGUEL, P. E.; SARMIENTO, Y. Hipertensión arterial, un enemigo peligroso. Acimed, La Habana, v. 20, n. 3, p. 92-100, 2009.

NAVARRETE, C.; GIL, J.; DURANGO, D.; GARCIA, C. Extracción y caracterización del aceite esencial de mandarina obtenido de residuos agroindustriales. Dyna, Medellín, v. 77, n. 162, p. 85-92, 2010.

QUIJANO, C.; PINO, J. Change in volatile constituents during the ripening of cocona (Solanum sessiliflorum Dunal) fruit. Revista CENIC Ciencias Químicas, Cuba, v. 37, n. 3, p. 133-136, 2006.

RAMÍREZ, K.; ROJAS, O.; ALVARADO, P.; VEGA-BUDRIT, J. Obtención de xilosa a partir de desechos lignocelulósicos de la producción y proceso industrial de la piña (Ananas comusus). Uniciencia, Argentina, v. 26, n. 1-2, p. 75-89, 2012.

RODRÍGUEZ, I.; PIÑEROS, Y. Production of enzymatic complex in solid state fermentation by Trichoderma sp. using palm oil empty fruit palm oil bunch (EFB) as substrate. Vitae, Medellín, v. 14, n. 2, 2009

ROGEZ, H.; BUXANT, R.; MIGNOLET, E.; SOUZA, J.; SILVA, E.M.; LARONDELLE, Y. Chemical composition of the pulp of three typical Amazonian fruits: araca-boi (Eugenia stipitata), bacuri (Platonia insignis) and cupuacu (Theobroma grandiflorum). European Food Research and Technology, Berlin, v. 218, n. 4, p. 380-384, 2004.
RUIZ, A.; ARIAS, E. Fermentación alcohólica de mucílago de café con levaduras. Ciencia y Tecnología de los Alimentos, Medellín, v. 11, n. 1, p. 66-74, 2001.

SERNA, L.; JOSÉ, M.; ANGULO, J.; GÓMEZ A. Kinetics of alcoholic fermentation using guava (Psidium guajava) seed flour and dry mycelium of Aspergillus niger as nitrogen sources. Dyna, Medellín, v. 80, n. 180, p. 113-121, 2013b.

SERNA, L.; MERA, D.; ANGULO, J.; GÓMEZ, A. Cinética de fermentación alcohólica utilizando como fuente de nitrógeno harina de semilla de guayaba Psidium guajava. In: SIMPOSIO INTERNACIONAL DE BIOFÁBRICAS, 5., CONGRESO INTERNACIONAL DE FLUJOS REACTIVOS, 1., 2013, Medellín. Anales... Medellín: Universidad Nacional de Colombia, $2013 a$. p. 21-22.

SERNA, L.; ROJAS, M.; RENGIFO, C. Hidrolizado de plumas de gallina como fuente de peptona para la producción de biomasa láctica. Vitae, Medellín, v. 19, n. 1, p. 162-164, 2013c.

SILVA, M. F.; LOPES, J. P.; AMARAL, F. C.; OZAKI, L. K. Processamento e avaliação da farinha de cubiu em diferentes condiçoes de armazenamento. In: REUNIÃO ANUAL DA SBPC, 62., 2010, Natal. Anais... São Paulo: SBPC, 2010. p. 1-4.

SILVA-FILHO, D. F.; YUYAMA, L. K.; AGUIAR, J. P.; OLIVEIRA, M. C.; MARTINS, L. H. Caracterização e avaliação do potencial agronômico e nutricional de etnovariedades de cubiu (Solanum sessiliflorum Dunal) da Amazônia. Acta Amazonica, Manaus, v. 35, n. 4, p. 399-406, 2005. http://dx.doi.org/10.1590/S004459672005000400003.

UBANDO-RIVERA, J.; NAVARRO, A.; VALDIVIA, M. Mexican lime peel: comparative study on contents of dietary fibre and associated antioxidant activity. Food Chemistry, London, v. 89, n. 1, p. 57-61, 2005. http://dx.doi.org/10.1016/j. foodchem.2004.01.076.

VARGA, F. J.; KOLODZIEJ, B. J. The copper, iron, zinc, magnesium, manganese, and calcium content of the western basin of Lake Erie. The Ohio Journal of Science, Ohio, v. 74, n. 5, p. 325-329, 1974.

YUYAMA, L. O.; MACEDO, S.; AGUIAR, J.; FILHO, D. S.; YUYAMA, K.; FAVARO, D.; VASCONCELLOS, M. Quantificação de macro e micro nutrientes em algumas etnovariedades de cubiu (Solanum sessiliflorum Dunal). Acta Amazonica, Manaus, v. 37, n. 3, p. 425-430, 2007. http://dx.doi.org/10.1590/S004459672007000300014.

YUYAMA, L.; BARROS, S. E.; AGUIAR, J.; YUYAMA, K.; FILHO, D. Quantificacao de fibra alimentar em algunas populacoes de Cubiu (Solanum sessiliflorum Dunal), Camu Camu (Myrciaria dubia (H.B.K) Mc Vaugh) e Acai (Euterpe Oleracea Mart). Acta Amazonica, Manaus, v. 32, n. 3, p. 491-497, 2012. http://dx. doi. org/10.1590/1809-43922002323467. 